\title{
The prophets and Sodom: The prophetic use of the Sodom and Gomorrah theme
}

\author{
J A Loader \\ University of South Africa
}

\begin{abstract}
The prophets and Sodom: The prophetic use of the Sodom and Gomorrah theme

The use made of the Sodom and Gomorrah theme by the pre-exilic prophets is investigated first in the book of Osiah, where most of the 'Sodom passages' occur, after which other eighth-century prophets as well (as later pre-exilic prophets) are incorporated into the investigation. Finally, the complex of prophetic motifs is related to the Sodom story in Genesis 18-19. It is argued that the narrative is a unit, dating from the seventh century BCE, about a crisis in social values and about punishment which does not jeopardise God's righteousness towards individuals. Far from being at variance with the prophetic perspective, its trust is thoroughly compatible with the way in which the prophets used the Sodom theme during the eighth and in subsequent centuries.
\end{abstract}

It is frequently remarked in commentaries on Genesis $18-19$, where the story of Sodom and Gomorrah is found, that the Sodom motif occurs often in the Hebrew Bible. This is quite true. Reference is made to Sodom in Genesis 10:19;13:10, 12, 13, and in Genesis 14, as well as twice in the Book of Deuteronomy (Dt 29:22;

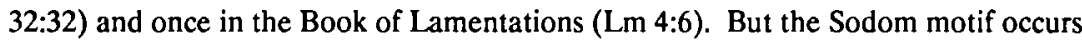
most of all in the prophetic literature (Is $1: 9,10 ; 3: 9 ; 13: 19 ;$ Jr 23:14; 49:18; 50:40; Ezk 16:44-58; Hs 11:8; Am 4:11; Zph 2:9). It is also found, moreover, in many other Jewish texts (the Apocrypha, Pseudepigrapha, Philo of Alexandria and Flavius Josephus), as well as in early Christian writings like the New Testament and several Fathers. What is surprising, however, is that such an obviously important motif has 
not as yet - if my observation is correct - been subjected to a thorough scrutiny. As I tried to do in a paper on the Sodom tradition in Rabbinic literature, delivered earlier to the Semitics Congress at the University of South Africa (Loader 1990: 231-245), I would now like to contribute another building block to the eventual filling of the gap.

What we do find in commentaries on Genesis (e g that of Von Rad) and on the prophets (like that of Wildberger on Isaiah), is the claim that the prophetic use of the Sodom motif is substantially different from that of the story of Sodom and Gomorrah in Genesis 18-19. This is most clearly put forward by Hans Wildberger in his commentary on Isaiah 1:4-9. Therefore he provides us with an excellent starting point for the development of my argument. We shall therefore begin by examining the use of the Sodom motif in the Book of Isaiah; then we shall compare the result with what we find in other eighth century and later pre-exilic prophets; finally, we shall relate our findings to Genesis 18-19.

\section{SODOM AND GOMORRAH IN THE BOOK OF ISAIAH}

The Sodom theme, as we may refer to the Sodom and Gomorrah tradition, occurs several times in the Book of Isaiah. Apart from Genesis, Isaiah ranks as the book containing the most passages in which the Sodom theme is found.

* Isaiah 1:9. Verses 9 and 10 contain two separate references to Sodom and Gomorrah belonging to two separate passages in the chapter (wv 4-9, 10-17). The 'arch-structure' found by Watts in Isaiah 1:2-23 is not convincing since the 'parallel thoughts' in the supposedly corresponding sections ( $v v 2 / / 21-23$; $3 / / 18-20 ; 4-5 / / 15 b-17 ; 6-7 b / / 10-15 a ;$ 'keystone': vv 7c-9) are too vague. As Wildberger points out, the division of sections between verses 9 and 10 is marked by the introductory appeal in verse 10 (the imperative שמער). This is not weakened by the fact that Sodom and Gomorrah are mentioned in both verse 9 and verse 10, because that is the reason why the two sections have been placed alongside each other.

After the exclamation of woe in verse 4 the sins and subsequent hardship of the Judeans are introduced. They have forsaken Yahweh $(v 4)$ and have been smitten as a consequence ( $v 6$ ). Part of this misfortune consists of the land and

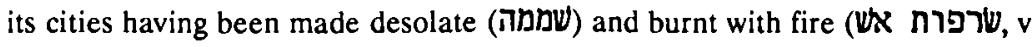
7). There is only one exception: Jerusalem (בת צירן) has been left over (ברחה, 1 , 8) like a booth in a vineyard or in a field of cucumbers. The imagery is clear: Only Jerusalem stands, while the rest of the land has been ravaged. 
Kaiser is correct that we know nothing of a destruction of Jerusalem in 701 $\mathrm{BCE}$, but this does not argue against dating the passage somewhat after this time, because the devastation of the country and the bare survival of Jerusalem after the campaign by Sennacherib in 701 BCE (cf Oppenheim 1955:287-288) fit the picture painted in our passage admirably. Verse 9 connects the Isaianic idea of the 'remnant' with the tradition of Sodom and Gomorrah. Had Yahweh not left a remnant of his people, they would have become like Sodom and Gomorrah, that is, they would have been completely wiped out (not 'almost', as contended by Watts, whose reading of כמעט with this meaning and after the verse divider does not remedy a supposed 'awkward sense', but creates one; they are 'almost' wiped out as it is (cf Van Uchelen 1981:158, who also reads כמעט in the apodosis, but as an intensifying conjunction). Watts thinks that 'the comparison to Sodom and Gomorrah does not quite fit', which should probably be attributed to his faulty reading of כמעט and his division of verse 9. Wildberger also finds the comparison surprising because Sodom and Gomorrah were not destroyed by military means. However, this need not surprise us because the tertium comparationis is again, as in the case of Deuteronomy $29: 22$, the final state of Sodom and Gomorrah, not the way in which they were destroyed. Whether we regard the verse as the rejection of a prophetic indictment in verses 2-8 (Van Uchelen 1981:161-163) or as a reference to the bare survival of Jerusalem in a devastated land, the function of the Sodom and Gomorrah tradition remains the same.

* The opening verse of the second passage in question (Is $1: 10-17)$ speaks of Sodom and Gomorrah in parallelism. Here the moot point is whether sacrifice is rejected in principle, which is not our immediate concern in this study (cf the discussion by Kaiser). What does concern us is that the leaders as well as the common people are addressed. 'Leaders of Sodom' and 'people of Gomorrah' are used in synonymous parallelism so that the two cities become one in function (cf Zeph 2:9, where Sodom and Gomorrah are also split in parallelism but one in function). The passage severely reprimands the whole cultic community for accompanying their external piety with injustice. Therefore we are justified in saying that their wickedness in general is scathed by calling them by the names of the classic examples of iniquity. We are not justified, however, in following Wildberger's pure guesswork about the existence of a tradition according to which the people of Sodom and Gomorrah were active in pious cultic practices but inactive in social justice. Because of the cult criticism and its reminiscences of Amos (Am 3:14; 4:4-5; 5:21-27) we can date this prophecy in 
the time of Isaiah.

* Isaiah 3:9 contains a gloss כסרם which makes the verse awkwardly long and metrically improbable (cf Duhm, Wildberger, Kaiser). For this reason it is probably late exilic. It reflects the tradition of Sodom's injustice in judgement, for it is added to a pronouncement about just this form of injustice in Jerusalem (הכרת פנ יהם, 'favouritism'). This is found in later Jewish traditions. It is possible that we here have the first instance of this specific form of wickedness associated with Sodom.

* In Isaiah 13:19 (and vv 20-22) we find a passage which is particularly germane to the thesis of Hillers $(1964: 53,75-76)$ that the mentioning of Sodom and Gomorrah in prophetic references to sudden destruction should be explained in terms of a traditional curse. Babylon is threatened with destruction like that of Sodom and Gomorrah. Watts has made out a convincing case that this, though surprising in the eighth century, can be dated in the time of Ahaz (1985:188, 200). 'At this time Babylon was the prime symbol of successful revolt against Assyrian sovereignty.' As Assyria was still Yahweh's rod, rebellion like that of Babylon 'by any of the small nations would be futile and, worse, it would be rebellion against God'. Because of her revolt against the rod of God, and therefore her bad example to Israel, Babylon is solemnly cursed to undergo the fate of the classic types of God's wrath. The fact that אלהים is not used here, is attributed by Kraetschmar (1897:87-88) to the fact that the phrase מהפכת אלהים אח סרם ראת עמרה $4: 11)$.

* A covenant tradition in Isaiah? Wildberger (1972:30) makes a remark in his discussion of Isaiah 1:4-9 which deserves our attention. He ascribes the knowledge of the pre-exilic prophets (Isaiah, Amos, Zephanaiah, Jeremiah, Ezekiel, and the northerner Hosea) about Sodom and Gomorrah to the fact that these cities were also known in the covenant tradition ('Bundestradition') with which these prophets were familiar. This is certainly a possibility made attractive by Weinfeld's idea of the relationship between the Sodom and Gomorrah theme and the covenant tradition. Weinfeld (1972:111) refers to some of the prophetic Sodom and Gomorrah texts (cf below) and contends that they 'occur in connection with breach of treaty'. Therefore he finds it legitimate to assume 'that the overthrow of Sodom and Gomorrah was conceived as the classic punishment of breach of covenant with the Deity'. In the 'treaty texts' the motif of cities being made a 
wasteland as punishment for their breach of treaties is constantly found. Therefore Weinfeld is correct in comparing the wasteland of the Sodom story to what we find in 'treaty texts' like Deuteronomy 29:22 and in other treaty-type texts from the Ancient Near East (Weinfeld 1972:109-112). But it does not follow that Sodom and Gomorrah were conceived of as having broken a covenant with Yahweh (Weinfeld does not say, 'an overthrow like that of Sodom and Gomorrah'). There has to be a covenant if it is to be broken, and a covenant between Yahweh and the people of Sodom and her sister cities would be difficult indeed to imagine. However, we may turn Weinfeld's idea (covenant - punishment) around and conclude that the classic illustration of punishment for offending the deity, contained in the the Sodom and Gomorrah theme, was applied in 'treaty texts' (like Dt 29:22) to the breaking of the covenant of Yahweh (punishment covenant). This was facilitated by the fact that the motif of laying waste the land of the offenders and making it salt occurred both in the Sodom and Gomorrah theme and in the treaty literature of the Ancient Near East. So the treaty-idea is indeed thinkable in the prophetic use of the Sodom theme, but not in the Sodom story of Genesis itself.

- Is there thus a fundamental difference between Isaiah and the Sodom story? In answering this question the differences between the covenant/prophetic tradition and the Sodom story should not be exaggerated. Wildberger expresses the suspicion that the two complexes are fundamentally ('wesentlich') different, which is just the opposite of Kaiser's opinion. According to Wildberger the fact that מהפכה is 'constantly' used in the covenant tradition (Dt 29:22, the emended text of Is 1:7 where כמהככת מהפת זרים is read instead of 13:19; Am 4:11; Jr 49:18; 50:40) shows that we have a different version of the Sodom and Gomorrah tradition before us. This argument is substantially devalued by the fact that the same root occurs several times in the Sodom story (הפכה in Gn 19:29, הכך in Gn 19:21, 25, 29). Moreover, Wildberger claims that an earthquake is suggested by מהפכה and implies that this differs from what we find in Genesis 19. In fact this is not at variance with the story (seismic activity or a מהפכה is quite compatible with the volcanic activity to which the sulphurous rain of the Sodom story points). So we conclude that the Sodom and Gomorrah theme found in Isaiah is similar to that found in other pre-exilic prophets and in the covenant tradition, but that its motifs are not fundamentally different from or irreconcilable with the narrative in Genesis 19 . The function of the use of the tradition in the book is twofold: To show that the sins of Judah/Israel are as bad as those of the classic examples of vice (Is $1: 10 ; 3: 9$ ), 
and to dramatise the total destruction to which Jerusalem had come near (Is 1:9) and to which Babylon was approaching (Is 13:19).

\section{SODOM AND GOMORRAH IN THE BOOK OF AMOS}

Our next prophetic reference is $A$ mos 4:11. There is widespread agreement that the verse is part of a clearly structured passage in Amos 4:4-13 (cf Wolff, Rudolph, Brueggemann 1965:1-15), while the relationship of verses 4-5 and 6-13 is disputed (Amr.ier sees them as independent but in judicious contrast to each other and Wolff dates vv 6-13 in the time of Josiah). The debate is not central to our interest and we may concentrate on the position of Sodom and Gomorrah in the rigidly built up section vv 6-13. There are five units in the catalogus calamitatum, as Rudolph calls it, each devoted to a plague (v 6 - hunger; vv 7-8 - drought; $v 9$ - crop disease; $v 10$ pestilence; $v 11$ - a catastrophe like that of Sodom and Gomorrah); and a conclusion (vv 12-13). At the end of each unit it is regularly said that Israel remained unrepentant. This means that the plagues were meant to bring about repentance. Even the climax of the visitations by Yahweh, the demolition by a מהפכה, failed to bring them to repentance. Therefore they are to prepare to be confronted directly with him (v 12).

The 'Sodom and Gomorrah formula' (כמהפכת אלהים אח סרס ראח עמרה) contains the only reference to אלהרים in Amos who regularly uses the name (cf Is 13:19; Jr 50:40, where the word אלהים also occurs). This is the clearest indication of the independence of the expression as an established formula (cf already Kraetschmar 1897:87-88). Wolff takes מהפכה to refer to the political demise of the Northern Kingdom in $721 \mathrm{BCE}$, claiming that the formula always means political destruction. This is not the case, for, as we have seen, the condition of the land, its barrenness and the unsuitability for human inhabitation is always meant (cf Rudolph). The natural interpretation of מהפכה as an earthquake is not only compatible with Genesis 19, where הפך occurs several times (vv 21, 25,29) and where the context can be interpreted as referring to an earthquake (which Wolff denies without argument; cf Wildberger on Is 1:4-9), but it is also compatible with Amos 1:1 where we hear of an earthquake which followed Amos's activity; the two earthquakes need not be the same (earth tremors are not rare in the country Rudolph).

Again Sodom and Gomorrah are the symbols of destruction, and as such stand at the pinnacle of a list of catastrophes. If Israel remained unrepentant even after such a castigation, it cannot be imagined what will bring them to repentance. 


\section{THE SODOM AND GOMORRAH THEME IN THE BOOK OF HOSEA}

Hosea 11:8 is the only text in the Old Testament where Admah and Zeboim occur together without Sodom and Gomorrah. The verse is part of a passage that is usually regarded as a unity (Hs 11:1-11; cf Wolff and Rudolph, but on the other hand Robinson who thinks that the chapter consists of four units). The passage begins with Ephraim's blindness to Yahweh's love (vv 1-4), the faithlessness of the people and its consequence ( $v$ 5-7), Yahweh's change of mind and its consequence (vv 8-11). There are several problems with the text of the passage (cf the extensive notes given by Wolff and Rudolph), but none of these affect our interpretation of verse 8 directly. The verse is structured in a precise parallelism. By means of a rhetorical question (cf Gn 39:9; 44:34; Jr 9:6; Ps 137:4 for which is not the same as the cry of lament; so Rudolph, rejecting Robinson's view) Yahweh says that he can neither surrender Ephraim/Israel nor make them like Admah and Zeboim. Elsewhere these two towns only occur in Genesis $10: 19 ; 14: 2,8$ and Deuteronomy 29:22 and, because of their exclusive association with Sodom and Gomorrah, obviously represent that tradition. They are again symbols of devastation, but not of wickedness. The sin of Ephraim in this context is idolatry ( $v 2$ ), although the social dimension is not absent elsewhere in the book (cf Hs 7:1; 12:9). But, as in Ezekiel 16, another dimension is added which makes the use of the Sodom and Gomorrah tradition very interesting. According to the implication of the rhetorical question Yahweh ought to destroy Ephraim as completely as he had destroyed Admah and Zeboim. This is indeed what Israel is threatened with in Hosea 9:6; 10:7, 8, 14, where the idea of destruction and a wasteland is present. But now Yahweh cannot bring himself to do to Ephraim what he had done to Admah and Zeboim. This is developed further by the highly suggestive use of הפך. This root is used in Deuteronomy 29, where the two cities are mentioned by name, and also in Genesis 19:21, 25, 29. This is scarcely coincidence. What Hosea is saying, is that Yahweh takes the מהפכה upon himself; instead of overturning Ephraim, his own heart is overturned. It is obvious that Yahweh intends not to destroy, but to save. In this regard the use of the Sodom and Gomorrah tradition (or the Admah and Zeboim tradition) is comparable to the use made of it in Ezekiel 16. Although no mention is made of the restoration of the ancient cities (cf Ezk 16:53), the fundamental tendency of the two passages is the same: Salvation instead of destruction. The מהפכה in God's heart can only mean that God suffers for the salvation of Israel. God undergoes the same fate as Sodom. This, in a special way, underscores Rudolph's remark at the end of his discussion of the next verse: 'Hier ist Evangelium im Alten Testament.' 
Why are Admah and Zeboim mentioned and not Sodom and Gomorrah? We have the same motif and the same function whether the former pair or the latter is used, and the four are clearly associated in three other passages (Gn 10:19; 14:2, 8; Dt 29:22). Why then only here no word about Sodom and Gomorrah? The most obvious answer is that given by Gunkel, Zimmerli and Westermann (1981:229): Hosea knew and used a variant form of the tradition in which Admah and Zeboim had the same function as Sodom and Gomorrah. But where would the 'northern tradition' come from if not from the south? The Dead Sea region suits the topographical requirements excellently, but such a wasteland is not found in the Northern Kingdom. Moreover, a single passage from a northern prophet remains a precarious basis for a hypothesis already burdened by several questionable assumptions. For these reasons it seems better to accept one Sodom and Gomorrah tradition in which Admah and Zeboim (and Zoar) also featured. Various selections could be made from the cities mentioned in the tradition. In fact we do not only have two - which one would have expected if there were two 'Sondertraditionen' but five such combinations of place names:

\author{
Sodom \\ Sodom and Gomorrah \\ Sodom, Gomorrah, Admah and Zeboim \\ Admah and Zeboim \\ Sodom, Gomorrah, Admah, Zeboim and Zoar
}

The evidence is pointing increasingly towards one basic tradition manifesting in several functions.

\title{
4. SODOM AND GOMORRAH IN THE LATER PRE-EXILIC PROPHETS
}

In Zephaniah 2:9 we have a prophecy against Moab and Ammon, embedded in an oracle stretching from verse 8 to the end of verse 11, which in turn is part of a context of oracles against different nations. In the parallelism Moab is likened to Sodom and Ammon to Gomorrah, which means both become like the sister cities of the Dead Sea plain (cf Is 1:10, where the two are also split in the parallelism but one in function). They will become desolate because of their haughtiness against Israel (v 10). The remark probably refers to an event such as described in 2 Kings 24:2, where we hear about raids by these two nations against Judah which took place about 602 BCE (Horst). This fits in well with the period of Zephaniah's activity. The prophecy against Moab and Ammon uses Sodom and Gomorrah as symbols of 
devastation in the same vein as the oracle against Babylon in Isaiah 13:19-22. However, no allusion is made to the last passage of the Sodom story, where Moab and Ammon are prominent (Gn 19:30-38). Although an argumentume silentio is not conclusive proof, we may look upon this as a sign of the existence of Sodom and Gomorrah traditions that were not dependent on the story of Genesis 18-19. Two other pointers in this direction are the use of גלהים instead of יהוד and the occurrence of Gomorrah in all but two references to Sodom (the exceptions are Is 3:9 and Lm 4:6; cf also Hs 11:8). Together with these, our text in Zephaniah 2:9 suggests that a tradition about the cities of Sodom and Gomorrah existed in which no mention was made of Israel's two eastern neighbours and in which 'the gods' featured. This tradition was the source on which the Genesis story as well as the prophets and other users of the theme drew.

Turning to the Book of Jeremiah, we find three references to Sodom and Gomorrah and one allusion to the cities ( $\mathrm{Jr}$ 20:16). The first reference is Jeremiah 23:14. It is part of a passage usually demarcated as verses 13-15 (cf Rudolph, Carroll, Holladay) which consists of a comparison between the prophets of Samaria ( $v 13$ ) and the prophets of Jerusalem (v 14), as well as an announcement of judgement ( $v 15)$. The comparison is to the detriment of the prophets of Jerusalem. The Samarian prophets did 'an unsavoury thing' (Carroll's translation of מפלה), but the Jerusalem prophets committed horrible things (שערורה). Whereas the former group caused Israel to apostatise after Baal, the latter group committed adultery and lies and strengthened the position of the evildoers. Their offence is moral, and moral offence is worse than cultic offence - a typical Jeremianic idea. This is why the prophets of Jerusalem are likened to the people of Sodom and the inhabitants of the city (who follow the guidance of their prophets) to the people of Gomorrah. The parallelism of the cities and the matching parallelism between a leading group in Jerusalem and the general populace is also found in Isaiah 1:10. Adultery and general wickedness accord well with the picture of the evil city in Genesis 19. Here the function of the Sodom and Gomorrah tradition is to typity the wickedness of the prophets and inhabitants of Jerusalem.

Two closely related passages are to be found in Jeremiah 49:18 and 50:40. In both cases we have prophecies against other nations, Edom in the first and Babylon in the second. Jeremiah 49:12-22 consists mostly of later expansions as suggested by the 'generality of reference which permits them to be used interchangeably' (Carroll). Part of this is verse 18 where Sodom and Gomorrah appear in the familiar expression כמהפכת סרם ועמרה, this time followed by ושכניה, 'and her neighbours' (i e Admah and Zeboim, cf Gn 10:19; Gn 14; Dt 29:22). The second main function of the Sodom and Gomorrah theme is thus again in evidence: 
The cities are the classic examples of total destruction. The same is the case in Jeremiah 50:40, where the neighbouring cities are mentioned again, but where אלהים is used instead of יהוה (another difference is that the nota accusativi is used here, but not in $\mathrm{Jr}_{\mathrm{r}}$ 49:18). As in the previous chapter and in Isaiah 13:19, the desolation is complete and vividly described by the use of animal images (albeit somewhat differently in $\mathrm{Jr}_{r} 49: 19$, but of $\mathrm{Jr}_{r} 49: 19-21$ and 50:44-46). The fate of Babylon is described with such close similarity to Isaiah 13:19 that Rudolph thinks it has been drawn from the earlier passage and that Jeremiah 49:18 shares in the dependence. It is possible that he is right in both instances (cf Carroll on the date of Jr 50: the grandiloquence and the insignificance of the actual changeover of power between the Babylonians and the Persians point to a date after $539 \mathrm{BCE}$ ). The context in Jeremiah 50 contains another interesting parallel to the Sodom and Gomorrah theme: In verse 38 a drought is announced over the waters of Babylon. The well watered land will become a wasteland. This is an established motif in the Sodom and Gomorrah theme (cf Gn 13).

Ezekiel 16:44-58 is perhaps, with the possible exception of Hosea 11:8 (cf above), the most noteworthy of the prophetic references to Sodom. The passage is usually demarcated as I have done (cf Fohrer, Zimmerli), and even if it is taken to be part of a larger unit a caesura is often indicated after verse 58 (cf Wevers, Brownlee 1986:242). Jerusalem first features as the daughter of her mother and the sister of her sisters (vv 44-46; cf also Ezk 23, where two cities are sisters with names); then follows an extended comparison to her sisters, of which Sodom is by far the most prominent ( $v v$ 47-50,51); next come an injunction (v 52), the restoration of the three sisters ( $v$ 53-55), and finally a conclusion about the disgrace of Jerusalem (vv 56-58).

The focus of our attention is, of course, drawn to the comparison between Jerusalem and Sodom. Gomorrah is not mentioned at all, but Sodom's neighbours are included by the addition of ובנוחיה, 'and her daughters', an ancient expression to indicate lesser neighbouring towns (Jdg 1:27; cf Zimmerli). Samaria also has such dependent towns, as does Jerusalem ( $v 48$ ). Sodom is the smaller sister, since the politically more prominent Samaria has to be the 'big' sister. However, in this passage Sodom has a more prominent role than Samaria (cf vv 48-50/51). The sisters can be expected to be wicked because their mother was a bad wife to her husband and a bad mother to her children. Sodom's sin was that it combined a luxurious life with insolence and social oppression ( $v$ 49-50). Then comes the most offensive thing that could be said of Jerusalem: Her wickedness is worse than that of Samaria who has been destroyed because of her sins and, horror of horrors, she even surpasses the wickedness of Sodom, the example par excellence of depravity 
and total destruction ( $v 50$ ). So both the aspects of the Sodom symbolism are found here - Sodom as the type of wickedness and as the arch-example of the destructive wrath of God. This is succinctly formulated by Neher (1979:484) when he says that Sodom is 'l'incarnation même de la mort morale et physique'. Accordingly Jerusalem can expect to undergo the same treatment as her sisters. However, the second surprise of the passage is found at this juncture. The punishment of total destruction is not worked out; Jerusalem will have to bear her shame as her sisters had to do earlier (vv 52,54,57,58), but she is not threatened with total demolition. This is unexpected and must have a good reason. All three of the sisters are to be restored to their former glory. Jerusalem indirectly interceded for her sisters by her shameful wickedness. For, if Yahweh wishes to restore Jerusalem, then he must also restore Sodom and Samaria since their wickedness was less than that of Jerusalem. Ezekiel thus appears as the vindicator of Sodom, and as such occupies a unique position in almost the whole Sodom and Gomorrah tradition.

The second aspect in support of the importance of Sodom's restoration for Ezekiel is to be found in the description of the temple river and the boundaries of the land (Ezk 47; shortly referred to by Neher 1979:490). Here we encounter the motifs of the paradise-like land (vv 1-12) and the borderline of the southeastern corner of the land ( $w$ 18, 19; cf $p 49$ ). Ezekiel pictured the river springing from the altar as lifegiving, coming as it does from the presence of God and therefore resembling the river of Paradise (Gn 2:10; cf Fohrer 1955:245). It flows eastward and down the Jordan valley in a southerly direction to reach the Dead Sea which will be 'healed' ( $\vee 8)$ with the exception of a few holes from which a supply of salt will be available ( $v 11)$. Plant and fish life will flourish and the whole region will be 'healed' or restored ( $v v 7,9)$. This is clearly part of the same pattern of ideas as those that we have been considering. The Dead Sea vicinity, which is desolate and salty, is to become the paradise that it was ( $\mathrm{cf} \mathrm{Gn} \mathrm{13:10).} \mathrm{The} \mathrm{Sodom} \mathrm{region} \mathrm{is} \mathrm{to} \mathrm{be}$ restored together with her sister Jerusalem as is said several times in Ezekiel 16, and now the worst of the sisters is to become the fountainhead of the other's restoration. Moreover, all of this is also supported by Ezekiel's description of the boundaries of the new, healed land. Whereas Genesis 10:19 excludes the Sodom and Gomorrah region from the land, Ezekiel includes this region. The eastern boundary reaches right down to the Dead Sea (Ezk 47:18); then the line proceeds further south and west to the Mediterranean ( $v 19$ ), so the traditional Sodom and Gomorrah area is clearly incorporated. The idea of restoration itself means that a new situation arises; consequently the incorporation of the Sodom area as part of the new dispensation makes sense if it was excluded from the land under the old dispensation. 
Ezekiel's highly original view of Sodom under the theme of 'Paradise lost' and 'Paradise regained' does not mean that he stood in a different line of tradition. On the contrary, we have seen that he received the traditional motifs that we have been studying earlier on and that he gave them an original interpretation. This is also apparent in Ezekiel 16:50, where Genesis 18:20 is interpreted (Yahweh sees the wickedness, $\mathrm{T}$ in both cases, before he does something about it; cf Brownlee). It is also evident from the dependence of Ezekiel's restoration motif on the dialogue between Abraham and Yahweh (while the latter is about the question whether Sodom can be saved because of the innocence of some people, the former is about the restoration of Sodom because of the guilt of others). This in turn supports my date for the Sodom story, which must be earlier than Ezekiel. Therefore Zimmerli's question (also asked by others; cf Schlosser 1973:19) about the description of Sodom's sins in verse 49 can also be answered. The gluttony, complacency and social irresponsibility should not be ascribed to a variant tradition as opposed to a 'mainline' tradition about the sexual sins depicted in Genesis 19. Ezekiel's view is not even much of an adaptation, which arose from social conditions in Israel, of the wickedness motif found in Genesis 18-19, although the social focus of the prophecy is in keeping with these conditions. Ezekiel's social motif is essentially the same as that of the Sodom story. For, as Brownlee argues, the sexual violence of the Sodomites is also a form of social violence or oppression.

In conclusion we can say that Sodom still features as the symbol of wickedness and destruction in spite of Ezekiel's restoration ideas because it is still the yardstick - if anyone is worse than Sodom, then he or she is the worst. But also: If Sodom can be restored to glory, then anyone can.

\section{THE MOTIFS ASSOCIATED WTTH THE SODOM THEME IN THE PRE- EXILIC PROPHETS}

Let us briefly summarise the prophetic Sodom motifs:

- From the eighth to the sixth centuries the Sodom and Gomorrah motif constantly functions as the symbol of wickedness and as the symbol of total destruction, sometimes in one text (Ezk 16).

- The sin of Sodom and Gomorrah is often seen by the pre-exilic prophets as social in nature (Isaiah, Jeremiah, Ezekiel), or the punishment is associated with such wickedness (Amos; the same perspective can be seen in Lm 4). 
- Once ( $\mathrm{Jr}$ 23:14) it is seen as sexual sin, while the idolatry spoken of by Hosea in association with the Admah and Zeboim motif also has such overtones.

- Those who are compared to Sodom and Gomorrah or whose destruction is compared to that of the cities of the plain can be Jerusalem/Judah or Ephraim/ Israel, but the same can be said of other nations or cities (Babylon in Is 13:19; Jr 50:40; Edom in Jr 49:18; Moab and Ammon in Zph 2:9), and sometimes a specific group of leaders are seen as 'Sodomites' (Is 1:10; Jr 23:14).

* The social motif is always associated with Judah/Israel.

* If the reference to Sodom in Isaiah 3:9 is a gloss, the social function of the Sodom motif has been developed in late exilic times to include favouritism in the administering of justice, which would be a prelude to later Jewish use of the theme.

* Twice the Sodom theme is used to achieve a positive end, viz in Hosea 11, where God himself undergoes the lot of Admah and Zeboim/Sodom, and in Ezekiel 16 where Sodom and the other cities are restored to happiness by God.

\section{THE RELATIONSHIP BETWEEN GENESIS 18-19 AND THE PROPHETS}

If we are to decide whether the prophets represent a 'Sodom tradition' different from what we find in the story of Sodom and Gomorrah in Genesis 18-19, we shall have to pay attention to the composition, meaning and date of this narrative.

* The organisation of the narrative can be presented as follows:
A $\quad 18: 1-16$
Three men visit Abraham
B $18: 17-33$
C $\quad 19: 1-26$
1-11
$12-22$
Abraham's question about Sodom
23-26
God's wrath over Sodom
Two messengers visit Lot
Rescue from Sodom
Destruction of Sodom
B $^{1} \quad 19: 27-29$
Abraham witnesses the destruction
A $19: 30-38$
Lot and his daughters 
The symmetry of the narrative can be seen in various aspects of its structure.

First we may note that the narrative has a central section (C) in which a crescendo is developed. In this part the destruction story proper is set out in three scenes. Here we find a progression from the arrival of the messengers and their confrontation with the men of Sodom ( $v$ 1-11) to the rescue of Lot and his family ( $v$ 12-22) and then to the actual destruction of the city (vv 23 26). The progressive line in Section $C$ is heightened by the mutually opposing elements of haste and retardation in its centre: Having several times heard the injunction to flee for their lives ( $v v 12,15)$, which has a tone of serious urgency, and having repeated it himself to his sons-in-law ( $v 14$ ), Lot still hesitates ( $v 16$ ). This creates tension, which is developed further by the urgent way in which the messengers physically compel Lot's family to leave, and by the command to hurry without even looking back ( $v$ 16-17). The same forces of urgency and delay are employed in the ensuing conversation between Lot and God: On the one hand Lot finds time to request an alternative refuge and on the other God rushes him (מרו) and makes the destruction dependent on the speed with which Lot can get away (wv 18-21).

An even more important observation is that the whole unit has a concentric structure. Working from the centre outwards, we find a Section $B^{1}$ that corresponds to Section $B$, and, on the outer sides, a Section $A^{1}$ that corresponds to Section A.

The inner circle, arranged as it is around the central section (C), serves to involve Abraham in the Sodom story. First, Abraham discusses the impending doom with God in a prelude to the destruction (Section $\mathrm{B}=18: 17-33$ ), and, subsequent to the event itself, he looks at the aftermath of what has happened (Section $\left.B^{1}=19: 27-29\right)$. Encircled by 'prelude' and 'aftermath', the Sodom story is integrated into the Abraham story. Without having noticed the concentric structure, Gunkel (1910:xl) nevertheless observed a link between what I call Section B and Section B1. According to him the story-teller's keen insight in psychological processes made him link Genesis 18: 20-21 (B) to 19:27$28\left(B^{1}\right)$ - in the second passage Abraham satisfies his need to find out what the significance of the reference to Sodom's guilt in the first passage was.

The outer circle is marked by an antecedent in which three men visit Abraham and talk about his offspring (Section $A=18: 1-16$ ), and a postscript about Abraham's relatives and their offspring (Section $A^{1}=19: 30-38$ ).

This carefully planned pattern is consistent with the careful overarching composition of the Genesis/Pentateuch stories. The different sections are neatly sewn together at the seams. As the Primeval History (Gn 1-11) is in- 
terlocked with the Patriarchal History (Gn 12-50) by means of introducing Abraham in Genesis 11, and as the Patriarchal History in turn is dovetailed into the Exodus Story (Ex 1-15) by the overlapping features of the figure of Jacob and the locality of Egypt, so the sections of the Sodom story are also welded together: The visit to Abraham by the three men (Section A) prepares for the discussion about Sodom between Abraham and one of them (Section B), whereas the other two, who leave for Sodom, can be identified with the messengers who arrive in Sodom (Section C) (cf Gn 18:16, 17, 22; 19:1). Moreover, the dialogue in Section B about the impending destruction naturally leads to the account of the destruction itself in Section $\mathrm{C}$ whereas Abraham's observing the devastation (Section $\mathrm{B}^{1}$ ) naturally follows it. Finally, the episode about Lot's daughters and their offspring (Section $A^{1}$ ) is a direct result of the catastrophe.

Whatever we may decide about the date of the author of this story and whatever we may conclude about the earlier form(s) of the tradition(s) found in our narrative, we may on the grounds of our analysis concur with Van Seters's obvious regard for the 'highly literate' abilities of the author (Van Seters 1975:210), and with the admiration of commentators from Dillmann and Gunkel to Von Rad and Westermann for the artistry evident in the narrative.

* As far as the date of the narrative is concerned, it should be placed between the late eighth century and the time of Ezekiel who is, as we have seen, dependent on the story. I shall now argue for a date in the seventh century.

Since, as I have argued, the narrative is a unity, albeit a unity containing much older traditional material, it would have to be dated after $587 \mathrm{BCE}$ if the famous conversation between Abraham and God (Gn 18:17-33) is to be dated after the exile. This frequently found dating of the passage can be countered with various arguments in addition to the terminus ad quem provided by Ezekiel:

Where is the quest for the preservation of God's righteousness to be placed in terms of the history of traditions? Westermann is quick to claim that it has its place in the complex of post-exilic proverbs about the fate of the righteous and the wicked. Now it is true that the צריק and the feature in many sayings of Proverbs 10-22. Even if we grant that these are late (cf Schmid 1966: 155-169, who calls the tendency to categorise people an 'Anthropologisierung der Weisheit'), Westermann's main point remains that the fate of the wicked must be negative and that of the righteous must be positive. Not much is gained by this insight, for the principle of correlation of deed and consequence is much older than the exilic period. The whole religion of Israel only makes sense on 
this premise. As Crenshaw (1970:384) puts it: '...priest, prophet and wise man labored under the assumption of a correlation between good conduct and earthly reward.' So the recognition of the nexus between deed and consequence in the sapiential tradition of Israel in itself helps us very little. The fact that the nexus occurs right through Israel's religion and right through her history does show, however, that the foundations for the crisis were laid early in the history of Israel and not only in the post-exilic wisdom movement. This is another argument in favour of retaining the individualistic perspective on the problem (cf above). The sapiential application of the nexus of deed and consequence involves everyday ethics as the responsibility of the individual (cf Schmidt 1976:147-148; Gese 1962:1576).

It is quite possible that the crisis itself, the doubt about God's justice evident in Genesis 18:23-25, could have been precipitated by the fall of Samaria in $722 \mathrm{BCE}$. Everything that can be said in favour of the fall of Jerusalem in $587 \mathrm{BCE}$ as the event that caused the problem of God's justice in relation to his acts in history, can also be said in favour of the fall of Samaria as such an event. Therefore it is not necessary to follow Westermann and Schmidt in assigning a post-exilic date to the passage. It seems quite possible to think in terms of the eighth century.

For instance, Psalm 78 was obviously written after the fall of Samaria and refers both to that event and to Jerusalem which is still intact (cf Ps 78:67-69). It theologises about Yahweh's rejection of the Northern Kingdom from a Southern Kingdom perspective. There is, further, no reason to say that the crisis could not have been evoked in even earlier times by people observing discrepancies in the system (which did in fact happen at an early stage in Egypt and Mesopotamia; cf Scharbert). The same kind of awareness of God's deeds in history ('Geschichtshandeln') is also found in the Mesa Inscription from the ninth century $B C E$, where the deity is visualised as involving himself in the history of a city/nation (cf Albright 1955:320). In addition there is evidence of Deuteronomic awareness of exactly the problem which interests us here, viz the lot of innocent people among a mass that is going to be killed. The fate of women, children and animals is handled with more sympathy than that of men (Dt 20:13-14). Behind this law lie very old traditions of the so-called Yahweh wars. This makes it possible that we have before us proto-Deuteronomic ideas from the Northern Kingdom of about the eighth century BCE. By this I do not mean that the Sodom story itself is Deuteronomic, which would have required the presence of a prophet to warn the wicked beforehand, but that the agonising over Yahweh's justice to the innocent in the event of mass destruction may be 
related to Deuteronomic thought. At least it shows that the problem was thought about and theologised about before the exile.

So Schmidt and Westermann are not right in claiming that the problem of Yahweh's justice in its connexion with his acts in history only come to the fore since the fall of Jerusalem in $587 \mathrm{BCE}$. This event certainly had all the ingredients to cause the enigma of how God's justice can be squared with the belief that he controlled the fate of nations, but so did the fall of Samaria and even the fate of communities in earlier Israelite history. If Yahweh could bring the Assyrians to Samaria, if Chemosh could bring the Moabites against Nebo (cf Albright 1955:320), and if the Deuteronomic law of wars could reflect on the lot of minority groups in cities, then the whole concept of Yahweh's 'Geschichtshandeln' and its relationship to the problem of our passage is thoroughly thinkable in the pre-exilic period.

Moreover, the classic prophets of the eighth and seventh centuries obviously work with the presupposition that Yahweh controls the history of nations and that he does so according to the principle of deed and consequence. But the other side of the coin is that he is also supposed to control the lot of individuals whose deeds do not warrant death or captivity. How is this to be explained? Why did these good people also undergo the effects of God's wrath?

The question is answered in various texts from this period. In Ezekiel 18 we find a classic exposition of the correlation of deed and consequence with reference to the idea of individual responsibility. Collective guilt and collective merit are explicitly rejected. The same is found in Ezekiel 14:12-20. But it is an escape directly into the problem of justice and therefore of theodicy: What if individuals are innocent and in fact are not saved? From a collective perspective the problem does not arise, but from an individualist perspective it grows into a conflict in which nothing less than the concept of God and a moral world order is at stake.

This question is answered by what we have in Genesis 18:17-33. Here we find the problem itself on two levels and therefore an answer on two levels. The one could be called the collective level. It is repeatedly stated that a community can be saved on account of (בעבר) a small group of righteous people. A little goodness outweighs much wickedness. This is the exact opposite of the emphatic denial of Ezekiel (cf Ez 14:14), and conversely related to Qohelet's pessimistic notion that a little of the negative force in life outweighs much of the positive force (Ecc 10:1-2). The other level in our passage could be called the individual level. Abraham is made to discontinue his diminuendo of numbers at ten to show that no righteous group is to be found in Sodom. But the story goes 
on to show that the good Lot himself is saved. His wife perishes on their way out, which is her own fault and not that of the wicked community. All of this goes to show that our author - for that is what the creator of the conversation between Abraham and Yahweh is - believed that individual retribution does occur.

For the reasons given above I cannot concur with Westermann (and many others) in assigning an exilic date to the passage (cf also Schmid 1976:151-152).

A last argument for this dating of the whole Sodom story is provided by the anti-urban motif in the narrative. The sinfulness of life in the city is contrasted with the rustic virtue of hospitality depicted in the opening passage of the narrative. Abraham and his environment stand over against the men of Sodom and their environment, while Lot, showing as he does respect for the rustic ideals, is presented as a tragic illustration that the nomad or at least rustic way of life is not respected in the city. This points to a pre-exilic time for the story as a whole. The latest evidence that could be interpreted as anti-urban is found in Jeremiah's example of the Rechabites (Jr 35). Since the composer of the complete story is the one who created the careful contrast between the rustic Abraham and the urban Sodomites, as well as the figure of Lot as the tragic link between the two, he will have to be dated in the pre-exilic period. If we allow sufficient time during the monarchy for the development of this kind of social conflict and the resulting moral conflict, the most likely period would be the eighth/seventh century (cf above).

This conclusion supports the direction taken by Schmid (1976) in his objections to the early dating of $J$, whose work, according to a wide consensus of opinion, is also found in the Sodom story. My analysis, if accepted, would add another argument to those developed throughout his book ( $\mathrm{cf}$ the concluding examples; Schmid 1976:154-166), although I would not prefer a date for the Sodom story quite as late as the early sixth century BCE even if this still qualifies as pre-exilic (cf above on Ezekiel's dependence on the Sodom story).

- Our last concern, that of the meaning of the narrative, has been presenting itself in the course of these arguments. As we have just seen, the Sodom story is about a conflict of social values. Our narrative depicts an anti-social deed of oppression against helpless wanderers (we may even call them 17 ). The sexual motif is not used for its own sake, but as the manifestation of anti-social behaviour and the decay of traditional social values.

The story is also about the punishment of this wickedness. The Sodom story is organised as a narrative text, and the function of this text is to argue that 
God punishes wickedness, but that he also respects individual innocence in the midst of mass guilt, so that it is even possible that the guilty may be saved for the sake of the innocent. If this does not happen, then the innocent are saved individually (like Lot and his daughters). Mass as well as individual guilt (like that of the wicked cities on the one hand and that of Lot's wife on the other) is punished, but not at the price of justice. So God is vindicated in the face of doubt about his righteousness when he intervenes in human affairs.

- These observations lead to a clear conclusion: There is no fundamental difference between the Sodom theme in the story of Genesis and in the preaching of the pre-exilic prophets.

- The social aspect of the sin of Sodom is as prominent in the story as in the prophets. Therefore no justification can be found for regarding the story as occupied with sex as opposed to the prophets who are then seen as the only exponents of the social aspect of the tradition.

- Sodom (and Gomorrah) is the symbol of wickedness as well as of punishment for the prophets, where the focus may be on either or on both symbolic values, and also in the narrative of Genesis.

- The eighth century prophets cannot be dependent on the Genesis narrative since they are older than the story in that form. Only Ezekiel is clearly dependent on the story.

- Both the prophets and the author of the narrative, who was a contemporary of the seventh century prophets and possibly also of Isaiah, drew on a common stock of earlier traditional material in which the barren wasteland of the Dead Sea plain was explained in terms of the motifs of wickedness and punishment. We can no longer reconstruct the form of this tradition, but we can note with surprise that the social motif in the Sodom theme was respected in the later Jewish tradition, whereas the Fathers of the Church seem to have sacrificed it in favour of - if I may be allowed the pun - a homosexual reading of the story, apparently unaware of the corrective to such a reading latent in the prophetic use of the theme.

\section{Works cited}

Albrektson, B et al (eds) 1981. Remembering all the way... Leiden: Brill. (OTS 21.)

Albright, W F 1955. Palestinian inscriptions, in Pritchard 1955:320-322.

Amsler, S 1965. In Jacob, Keller \& Amsler 1965. 
Brownlee, W H 1986. Ezekiel 1-19. Waco: Word Books. (Word Biblical Commentary 28.)

Brueggemann, W 1965. Amos 4 and Israel's covenant worship. VT 15, 1-15.

--- 1982. Genesis. Atlanta: John Knox. (Interpretation.)

Carroll, R P 1986. Jeremiah: A commentary. London: SCM. (OTL.)

Crenshaw, J L 1970. Popular questioning of the justice of God in Ancient Israel. ZAW 82, 380-395.

Dillmann, A 1892. Die Genesis. 6. Aufl. Leipzig: Hirzel. (KeHAT.)

Duhm, B 1902. Das Buch Jesaia. 2. Aufl. Göttingen: Vandenhoeck. (GHKAT.)

Fohrer, G 1955. Ezechiel. Tübingen: Mohr. (HAT 13.)

Gese, H 1962. s v Weisheit. $R G G, \mathrm{Bd} 6$.

Gunkel, H 1910. Genesis. 3. Aufl. Göttingen: Vandenhoeck. (GHKAT.)

Hillers, D R 1964. Treaty curses and the Old Testament prophets. Rome: Pontifical Biblical Institute. (Biblica et Orientalia.)

Holladay, W L 1986. A commentary on the Book of the Prophet Jeremiah, Chapters 1-25. Philadelphia: Fortress. (Hermeneia.)

Horst, F 1964. In Robinson \& Horst 1964.

Jacob, E, Keller, C-A \& Amsler, S 1965. Osée - Joël-Abdias - Jonas - Amos. Neuchâtel: Delachaux \& Niestlé. (Commentaire de l'Ancien Testament 11a.)

Kaiser, O 1981. Das Buch des Propheten Jesaja, Kapitel 1-12. Göttingen: Vandenhoeck. (ATD 17.)

Kraetschmar, R 1897. Der Mythus von Sodoms Ende. ZAW 17, 81-92.

Loader, JA 1990. The sin of Sodom in the Tahmud and Midrash. OTE 3, 231-245.

Neher, A 1979. Ezechiel, rédempteur de Sodome. RHPR 59, 483-490.

Oppenheim, A L 1955. Babylonian and Assyrian historical texts, in Pritchard 1955: 265-315.

Pritchard, J B (ed) 1955. Ancient Near Eastern texts relating to the Old Testament. 2nd ed. Princeton: Princeton University Press.

Robinson, T H \& Horst, F 1964. Die zwölf kleinen Propheten. 3. Aufl. Tübingen: Mohr. (HAT 14.)

Rudolph, W 1958. Jeremiah. 2. Aufl. Tübingen: Mohr. (HAT 12.)

--- 1966. Hosea. Gütersloh: Gerd Mohn. (KAT 13/1.)

--- 1971. Joel - Amos - Obadja - Jona. Gütersloh: Gerd Mohn. (KAT 13/2.)

Scharbert, J 1986. Genesis 12-50. Würzburg: Echter. (Die Neve Echter Bibel.)

Schmid, H H 1966. Wesen und Geschichte der Weisheit. Berlin: Töpelmann. (BZAW 101.)

... 1976. Der sogenannte Jahwist: Beobachtungen und Fragen zur Pentateuchforschung. Zürich: Theologischer Verlag. 
Schmidt, L 1976. 'De Deo': Studien zur Literarkritik und Theologie des Buches Jona, des Gesprüches zwischen Abraham und Jahwe in Gen 18:22ff und von Hi 1. Berlin: De Gruyter. (BZAW 143.)

Van Seters, J 1975. Abraham in history and tradition. New Haven: Yale University Press.

Van Uchelen, N A 1981. Isaiah 1:9: Text and context, in Albrektson et al (eds) 1981:155-163.

Von Rad, G 1964a. Das erste Buch Mose: Genesis. Göttingen: Vandenhoeck. (ATD 2-4.)

--- 1964b. Das fünfte Buch Mose: Deuteronomium. Göttingen: Vandenhoeck. (ATD 8.)

Wallis, G 1966. Die Stadt in den Überlieferungen der Genesis. ZAW 78, 133-148.

Watts, J D W 1985. Isaiah 1-33. Waco: Word Books. (Word Biblical Commentary 24.)

Weinfeld, M 1972. Deuteronomy and the Deuteronomic School. Oxford: Clarendon.

Westermann, C 1981. Genesis, 2. Teilband: Genesis 12-36. Neukirchen: Neukirchener Verlag. (BK 1/2.)

Wevers, J W 1969. Ezekiel. London: Nelson. (CB.)

Wildberger, H 1972. Jesaja, 1. Teilband:Jesaja 1-12. Neukirchen: Neukirchener Verlag. (BK 10/1.)

Wolff, H W 1965. Dodekapropheton, 1: Hosea. 2. Aufl. Neukirchen: Neukirchener Verlag. (BK 14/1.)

--- 1969. Dodekapropheton, 2: Joel und Amos. Neukirchen: Neukirchener Verlag. (BK 14/2.)

Zimmerli, W 1969. Ezechiel, 1. Teilband: Ezechiel 1-24. Neukirchen: Neukirchener Verlag. (BK 13/1.)

-.- 1976. I Mose 12-25. Zürich: Theologischer Verlag. (ZB.) 